\title{
Effect of some rearing systems on growth and development of the Egyptian sole (Solea aegyptiaca Chabanaud, 1927) larvae.
}

\author{
Safaa S. A. Aljilany ${ }^{1}$, Ragab A. Mohammed ${ }^{1}$, Hamed H. E. Saleh ${ }^{{ }^{*} \text {, }}$ \\ Ramadan M. Abou-Zied ${ }^{2}$ and Sobhy M. Allam ${ }^{2}$ \\ 1- National Institute of Oceanography and Fisheries (NIOF), Egypt. \\ 2- Animal Production Department, Faculty of Agriculture, Fayoum University, Egypt. \\ *Corresponding author: E-mail: hhsaleh90@gmail.com
}

\section{ABSTRACT}

This study was conducted to evaluate the optimum salinity and temperature on growth and development of Solea aegyptiaca larvae and weaning feed type on growth of Solea aegyptiaca post-larvae. The first experiment was tested five different salinities $(10,15,20,25$ and $30 \%)$. The results found that, no significant difference in growth rate, but the best performance and survival rate of larvae was at salinity $20 \%$. The second experiment was tested eight different water temperature $(16,17,18,19$, $20,21,22$ and $23^{\circ} \mathrm{C}$ ). The results showed that, the larvae under temperature $20{ }^{\circ} \mathrm{C}$ showed the highest growth rate, while the best survival rate was recorded at temperature $16^{\circ} \mathrm{C}$ under experimental conditions. The growth rate for larvae has been increased gradually with increasing temperature until $20^{\circ} \mathrm{C}$ then decreased, while survival rate was decreased gradually with increasing temperature. The third experiment was tested three different feed (Artemia $\left(\mathrm{T}_{1}\right)$, Artemia + artificial feed $\left(\mathrm{T}_{2}\right)$ and artificial feed $\left(\mathrm{T}_{3}\right)$ ) of Solea aegyptiaca post-larvae weaning. Results of growth performance parameters were highest with post-larvae fed on $\left(\mathrm{T}_{1}\right)$ compared to the other feeds $\left(T_{2}\right.$ and $\left.T_{3}\right)$. Larvae fed on $\left(T_{1}\right.$ and $\left.T_{2}\right)$ led to higher survival rate compared to fed on $\left(\mathrm{T}_{3}\right)$.

Keywords: Growth performance, development, survival rate, salinity, temperature, Solea aegyptiaca

\section{INTRODUCTION}

The common sole Solea solea and the Egyptian sole S. aegyptiaca (Family: Soleidae) are the most important sole species that occurs in the Egyptian waters. The common sole is highly appreciated fish by the Egyptians especially in the coastal communities because of its high quality flesh and is one of the commercially important fish in Egypt providing up to 90 million LE annually (Mehanna, 2014). The Egyptian sole (Solea aegyptiaca) is the most common species of soles that contributed about $6.5 \%$ of the total catch of trawl fishery, forming about $13 \%$ of the gross revenue of the trawling (Mehanna, 2007). Kariman (2009) recorded that catch composition of sole species during summer and winter seasons in Lake Qarun were more than 50 and $35 \%$, respectively.

The rearing methods for this species have been well documented (Dinis et al., 1999), although high mortalities during the weaning phase possibly due to inadequate nutrition and pathological problems (Zarza et al., 2003) as well as poor success obtaining eggs from captive breeders (Anguis and Canavate, 2005) are constraints for the continued development of the industry. Senegalese sole larvae are fed on live prey (rotifer, Brachionus plicatilis and Artemia sp.) during the first 40 days after hatching; although earlier weaning on inert feeds has been attempted (Canavate and FernandezDiaz, 1999; Dinis et al., 1999). The nutritional value of live prey is, therefore, a key 
factor in the success of larval rearing. Indeed, exhibits good growth during the larval period when fed on live prey (Vazquez et al., 1994; Dinis and Reis, 1995); the weaning, switch from live prey to compound diet feeding, induces poor growth and mortality (Dinis, 1992; Marin-Magan et al., 1995), weaning and metamorphosis which are accompanied by increased mortality rates (Rueda-Jasso et al., 2005). Standard feeding regimens during these periods represent a bottleneck for fish farmers due to the required administration to young larvae of live-feed usually characterized by: 1) variable availability and price fluctuations of Artemia cysts (Callan et al., 2003), which can reach 700\% (Moretti et al., 2005); and 2) poor hygienic conditions and high levels of pathogenic bacteria (Olsen et al., 2000; Olafsen, 2001). Metamorphosis is a crucial developmental phase in flatfish species.

The transformation from a symmetric pelagic larvae to an asymmetric benthic juvenile most conspicuously involves eye migration and craniofacial remodeling. Other transformations are recalibration of vision, changes in skin pigmentation and scale patterns, body shape, digestive tract and feeding behavior (Klaren et al., 2008). Weaning seems to be more difficult in sole. In addition, the early metamorphosis and acquisition of a peculiar non-proactive bottom-feeding behavior make early weaning an important issue in sole hatcheries. Engrola et al. (2007) studied three different strategies of weaning trying to find out the optimum Senegalese sole weaning scheme. In other approach, Engrola et al. (2009) recommended co-feeding regime with inert diet from mouth opening stage in Senegalese sole, as the co-fed sole were larger and have less tail deformities.

Salinity influences energy expenditure in fish; there is a significant energetic cost associated with the mechanisms used by fish to maintain osmotic balance (Boeuf and Payan, 2001). Osmoregulatory cost is generally lowest under isosmotic conditions (Jobling, 1994; Likongwe et al., 1996) and can increase when moving from stable to variable salinity environments (Hutchinson and Hawkins, 1990). However, an isosmotic environment is not preferential for all species where optimal salinity in terms of growth and condition can vary during onto-genetic development (Allen and Chec, 2007; Cardona, 2000; Partridge and Jenkins, 2002). From a review of the literature, Deacon and Hecht (1999) showed that in general, marine spawned fish grew better at salinities higher than the isosmotic level, whilst fresh water spawned fish had optimal growth below the isosmotic level. Information on species specific salinity tolerances and their interaction with ontogenetic development is useful for maximising growth rates, condition and development rates in aquaculture, whilst recognition of environmental conditions promoting enhanced growth, survival and recruitment can aid the identification of high-quality nursery habitats.

Temperature is the most important environmental parameter driving development, growth, and survival of marine fish during their early life history (Pepin, 1991). Some studies have demonstrated the existence of daily rhythms of temperature selection in fish in wild conditions. In such studies, fish showed daily migrations as they searched for a preferred temperature for physiological activity and growth (Gibson et al., 1998; Sims et al., 2006). In Senegalese sole, most studies on biological development and temperature have used a constant temperature of $20{ }^{\circ} \mathrm{C}$ (Parra and Yufera, 1999; Yufera et al., 1999; Canavate et al., 2006).

The aim of the present study was to assess the overall effects of salinity and temperature on the growth and development of the Egyptian sole (Solea aegyptiaca) during early life stages. Moreover, to investigate the effect of feed type on weaning post-larvae on growth and survival rates. 


\section{MATERIALS AND METHODS}

\section{Larvae- rearing conditions}

The Egyptian sole, Solea aegyptiaca larvae used in the present study were obtained from the experiment of spawning conducted in National Institute of Oceanography and Fisheries (NIOF), Shakshouk Fish Research Station, El- Fayoum Governorate, during the period from 14/12/2014 to 14/4/2015. The water used in these trials were obtained from Lake Qaroun and filtered through plankton net $50 \mu$ mesh size. Larvae were collected from the date of the emergence of larvae in spawning tanks, and incubated in tanks from 1 to 3 days after hatching (DAH) under temperature $18{ }^{\circ} \mathrm{C}$ and then transported to the experimental rearing tanks. Larvae were collected by plankton net $150 \mu$ mesh size. Larvae rearing was following up from $4 \mathrm{DAH}$ to metamorphosis stage. For each tanks, continuous aeration was gently. The average water quality criteria of all experimental rearing larvae are presented in Table (1). About $30 \%$ of water aquarium was changed twice every day. This experiment was carried out in 2 replicates for each treatment.

Table 1: Average values of water quality parameters during experiments periods (Mean \pm S.E).

\begin{tabular}{|l|c|c|c|}
\hline \multirow{2}{*}{ Parameters } & \multicolumn{3}{c|}{ Experiments larval rearing } \\
\cline { 2 - 4 } & Salinity & Temperature & Weaning post-larvae \\
\hline Temperature, ${ }^{\circ} \mathrm{C}$ & $17.75 \pm 1.1$ & -- & $19.25 \pm 1.05$ \\
\hline $\mathrm{pH}$ & $8.29 \pm 07$ & $8.31 \pm 0.08$ & $8.24 \pm 0.06$ \\
\hline Salinity, \%o & -- & $33 \pm 3$ & $33 \pm 1$ \\
\hline Dissolved oxygen, $\mathrm{mg} / \mathrm{l}$ & $8.55 \pm 0.35$ & $7.7 \pm 0.7$ & $8.5 \pm 0.5$ \\
\hline Total ammonia, mg/l & $0.72 \pm 0.04$ & $0.62 \pm 0.16$ & $0.53 \pm 0.08$ \\
\hline Un-ionized ammonia, mg/l & $0.037 \pm 0.002$ & $0.035 \pm 0.017$ & $0.031 \pm 0.004$ \\
\hline Nitrite, $\mathrm{mg} / \mathrm{l}$ & $0.326 \pm 0.005$ & $0.258 \pm 0.069$ & $0.218 \pm 0.03$ \\
\hline Nitrate, $\mathrm{mg} / \mathrm{l}$ & $1.19 \pm 0.005$ & $1.11 \pm 0.21$ & $1.02 \pm 0.13$ \\
\hline
\end{tabular}

\section{Culture of live foo}

The live food organisms used in this study were the microalgae Nannochloropsis oculata, the rotifer (Brachionus plicatilus) and Artemia.

The golden unicellular alga Nannochloropsis oculata, obtained from the National Institute of Oceanography and Fisheries, Marine Hatchery Lab (AlexandriaEgypt). The culture of Nannochloropsis oculata was grown in glass flasks (capacity 1 liter ), at increased growth transported to transparent plastic bags from 20 to $40 \mathrm{~L}$ water capacity. The water used in microalgae culture was filtered through plankton filter $1 \mu$ mesh size. The cultures were grown under controlled laboratory conditions at temperature $\left(20^{\circ} \mathrm{C} \pm 3^{\circ} \mathrm{C}\right)$, salinity was $33 \%$, $\mathrm{pH}$ was from 8.11 to 8.27 , continuous aeration, illumination for alga culture was provided by fluorescent lights ( $24 \mathrm{~h}$ light). Each flask was regularly swirled daily by hand to detach adhered algal cells from the walls of flasks. Nannochloropsis oculata was fertilized with media as $1 \mathrm{ml}$ Super phosphate solution (5g Super phosphate in $1 \mathrm{~L}$ distilled water) and $1 \mathrm{ml}$ Urea solution (5g Urea in $1 \mathrm{~L}$ distilled water) per $1 \mathrm{~L}$ of Nannochloropsis oculata per day.

The rotifer, Brachionus plicatilus, was obtained from the National Institute of Oceanography and Fisheries, Marine Hatchery Lab (Alexandria- Egypt). Rotifer cultures were carried out using filtered saline water by plankton filter $30 \mu$ mesh size at $33 \%$ salinity using Nannochloropsis oculata as exclusive food $\left(5 \times 10^{5} \mathrm{cell} / \mathrm{ml}\right)$. The culture of rotifers was grown in tanks (capacity 500 liter). Rotifer cultures were carried out under defined illumination with a photoperiod of 12:12 light:dark, $\mathrm{pH}$ ranged from 8.11 to 8.27 , temperature ranged from 20 to $23^{\circ} \mathrm{C}$, continuous aeration was gently. The maintenance of rotifers was depending on the enrichment with 
microalgae at a very high density to obtain high density of rotifers. Once the water containing the rotifer cultures become clear, the rotifers will be in their highest density and again must be fed. The cultures received a continuously supply of commercial yeast.

Artemia cysts (Artemia International LLC, U.S.A) were brought from commercial market in Cairo, Egypt and they "hatched" with the addition of saline water as the following: A rectangular hatching glass aquaria ( $25 \mathrm{~L}$ water capacity) equipped with continuous aeration and heater with thermostat (JAGER 3609 Aquarium Heater, Automatic heater, Germany). Water salinity was 33\%. The heater with thermostat was added to keep water temperature at $25^{\circ} \mathrm{C}$. The aeration was set on high rate. Water $\mathrm{pH}$ was from 8.11 to 8.27 . The weight of cysts determined before adding to the glass aquaria at a density of $4 \mathrm{~g}$ per 14 liter. Artemia hatching were carried out under defined illumination with a photoperiod of 24 light. Under these conditions, the cysts hatched after about 20 hours. The hatched Artemia was buoyant on the surface water.

\section{Larvae feeding regime}

Larvae opened their mouth at about $3 \pm 1 \mathrm{DAH}$ and started to feed. Larvae were transported to the larval rearing tanks, after the start of the exogenous feeding, at a density of 80 larvae per litter. Solea aegyptiaca larvae were rearing from 4 DAH until metamorphosis stage, adopting a feeding regime based on live food only. Larvae were fed on Rotifer (20 individuals (ind.)/ml) from 3 DAH until 15 DAH. From 8 DAH, larvae fed on newly hatched Artemia nauplii (10 ind./ml) (Table 2). Artemia nauplii were introduced at $8 \mathrm{DAH}$ and their density was gradually increased, becoming the only prey offered from $16 \mathrm{DAH}$. Feed was offered by hand at three meals/day (9:00, 13:00 and 16:00 h). Microalgae (Nannochloropsis oculata) at a final concentration of $5 \times 10^{5}$ cells $/ \mathrm{ml}$ were also added to the rearing tanks from first feeding. By the age of metamorphosis stage, it fed on Artemia metanauplii (8-12 ind./ml).

\section{The first experiment: Effect of salinity}

The first experiment was conducted to investigate the effect of salinity, $(10,15$, 20,25 and $30 \%$ ) on growth performance, metamorphosis stage and survival rate of Solea aegyptiaca larvae. Larvae of $2.72 \pm 0.02 \mathrm{~mm}$ initial mean length were randomly distributed into the experimental circular plastic tanks of $25 \mathrm{~L}$ water capacity by using 10 experimental plastic tanks.

Table 2: Feeding regime based on live food organisms.

\begin{tabular}{|l|c|c|c|}
\hline \multicolumn{1}{|c|}{ days } & Number/ ml & Amount/ tank & Number/ tank \\
\hline Rotifer, Brachionus plicatilus & $20 \mathrm{ind} . / \mathrm{ml}$ & 1 liter/ tank & 20000 ind./ tank \\
\hline 3- 7 DAH & $20 \mathrm{ind} . / \mathrm{ml}$ & 0.5 liter/ tank & $10000 \mathrm{ind} . /$ tank \\
\hline 8-15 DAH & $10 \mathrm{ind} . / \mathrm{ml}$ & 1 liter/ tank & 10000 ind./ tank \\
\hline Artemia nauplii & $10 \mathrm{ind} . / \mathrm{ml}$ & 2 liter/ tank & 20000 ind./ tank \\
\hline 8-15 DAH
\end{tabular}

\section{The second experiment: Effect of temperature}

The second experiment was conducted to investigate the effect of water temperature, $\left(16,17,18,19,20,21,22\right.$ and $\left.23^{\circ} \mathrm{C}\right)$ on growth performance, metamorphosis stage and survival rate of Solea aegyptiaca larvae. Larvae of 2.72 $\pm 0.02 \mathrm{~mm}$ initial mean length were randomly distributed into the experimental rectangular glass aquaria of $25 \mathrm{~L}$ water capacity by using 16 experimental glass aquaria. 
The temperature was controlled by a heater with thermostat (JAGER 3609 Aquarium Heater, Automatic heater, Germany).

\section{The third experiment: Effect of feed type on weaning post-larvae}

The fourth experiment was conducted to investigate the effect of feed type on weaning post-larvae, (Artemia $\left(\mathrm{T}_{1}\right)$, Artemia + artificial feed $\left(\mathrm{T}_{2}\right)$ and artificial feed $\left(\mathrm{T}_{3}\right)$ ) on growth performance and survival rate of Solea aegyptiaca post-larvae. Newly hatched larvae of Solea aegyptiaca were reared in $25 \mathrm{~L}$ water capacity glass aquaria and plastic tanks, from 4 DAH to metamorphosis stage, and then they were transported to the weaning aquaria until the end of the experiment. The weaning trail, were carried out in rectangular glass aquaria containing 25 liters of saline water. For each glass aquarium aeration was adjusted and provided by sand layer of $2 \mathrm{~cm}$ in the bottom of each aquarium. Post-larvae of $11.50 \pm 0.10 \mathrm{mg}$ initial mean weight, were randomly distributed into the experimental aquaria of $25 \mathrm{~L}$ water capacity by using 6 experimental glass aquaria at density of 6 post-larvae/L. Post-larvae rearing was following up from metamorphosis stage (36 DAH) until the end of the experiment (100 days trial period, from 5/2/2015 to $16 / 5 / 2015$ ), with a feeding regime based on artificial diet (Table 3) and live food. By the age of metamorphosis stage, it fed on Artemia metanauplii (8-12 ind./ml). Feeding regime post-larvae were fed 4 liter Artemia/ T1, 2 liter Artemia + 1g artificial diet/ T2 and 2g artificial diet/ T3 per day.

\section{Parameters measurements}

At the end of the experiment, growth performance and survival rate were calculated as follows:

- Total length gain $(\mathrm{mm})=$ final length, $\mathrm{mm}$ - initial length, $\mathrm{mm}$.

- Average daily length gain $(\mathrm{mm} /$ day $)=$ average length gain, $\mathrm{mm} /$ experimental period, day.

- Weight gain $(\mathrm{mg})=$ final weight, $\mathrm{mg}$ - initial weight, mg.

- Average daily weight gain (mg) = average weight gain, $\mathrm{mg}$ / experimental period, day.

- Specific growth rate $(\mathrm{SGR}, \%)=[(\ln$ final weight $-\ln$ initial weight $) /$ period in days $]$ $\times 100$, where $\ln$ is the natural $\log$.

- Condition factor $\left(\mathrm{mg} / \mathrm{mm}^{3}\right)=($ wet weight $) /\left(\right.$ total length $\left.{ }^{3}\right) \times 100$.

- Survival rate $(\mathrm{SR}, \%)=($ number of fish at end/ number of fish at start $) \times 100$.

Table 3: Ingredients and chemical composition of the diet used in the weaning post-larvae experiment.

\begin{tabular}{|l|c|l|c|}
\hline \multicolumn{1}{|c|}{ Ingredients, \% } & Weaning diet & \multicolumn{1}{c|}{ Chemical composition } & Weaning diet \\
\hline Fish meal, (CP 72\%) & 70 & Dry matter, DM \% & 91.24 \\
\hline Starch & 22 & Crude protein, CP \% & 50.40 \\
\hline Fish oil & 3 & Ether extract, EE \% & 14.00 \\
\hline Sunflower oil & 4 & Crude fiber, CF \% & 0.00 \\
\hline vit \& Min. * & 1 & Ash, \% & 7.09 \\
\hline------ & -- & Nitrogen free extract, NFE \%** & 19.75 \\
\hline------ & -- & GE, kcal/g*** & 4.853 \\
\hline
\end{tabular}

* Vitamins and minerals mixture each $3 \mathrm{Kg}$ of mixture contains: 1200000 IU Vit. A, 300000 IU Vit. D3, $700 \mathrm{mg}$ Vit. E, $500 \mathrm{mg}$ Vit. K3, $500 \mathrm{mg}$ Vit. B1, $200 \mathrm{mg}$ Vit. B2, $600 \mathrm{mg}$ Vit. B6, $3 \mathrm{mg}$ Vit. B12, $450 \mathrm{mg}$ Vit. C, $3000 \mathrm{mg}$ Niacin, $3000 \mathrm{mg}$ Methionine, $10000 \mathrm{mg}$ Cholin chloride, $300 \mathrm{mg}$ Folic acid, 6 mg Biotin, $670 \mathrm{mg}$ Panthonic acid, $3000 \mathrm{mg}$ Magnesium sulphat, $3000 \mathrm{mg}$ Copper sulphat, $10000 \mathrm{mg}$ Iron sulphat, $1800 \mathrm{mg}$ Zinc sulphat, $300 \mathrm{mg}$ Cobalt sulphat.

** Calculated by differences . *** Calculated according to NRC, 1993.

\section{Water quality analysis}

Water temperature and $\mathrm{pH}$ were measured daily by Combined meter $(\mathrm{pH} / \mathrm{EC} /$ TDS/ temperature, Mi 805). Salinity was measured daily by Refractometer (VITAL Sine SR-6, China). Dissolved oxygen (DO) concentration was determined 
titrimetrically according to the modified Winkler, full-bottle technique (Method 360.2; EPA, 1983). Water ammonia, nitrite and nitrate were determined by using Spectrophotometer model (LKB Bichrom UV visible spectrophotometer) according to the method described by APHA (1992). To determine un-ionized ammonia concentration, multiply total ammonia concentration by the percentage which is closest to the observed temperature and $\mathrm{pH}$ of the water sample (Swann, 1997).

\section{Estimation of eye migration stage}

Metamorphosis degree was evaluated on 20 larvae/ tank. Degrees of metamorphosis were divided into 5 phases: 1) symmetrical left and right eye position; 2) an asymmetrical position of the left eye and right eye, the left eye starts to migrate; 3 ) the migrating eye reaches at maximum the midline of the dorsal surface; 4) the migrating eye can be seen from the right ocular side or migrates within the dorsal side; 5) eye translocation is completed and the orbital arch is visible.

\section{Statistical analysis}

The data were analyzed by one-way ANOVA and significant differences were determined by Duncan Waller Multiple Range Test at 5\% level using SPSS Statistical Package Program (SPSS, 2008) 17, released version.

\section{RESULTS}

Generally, the total length of the larvae throughout the period of the study has been increased gradually with the larval development. Survival from hatching till 7 DAH was high in all trials larval rearing under all treatments, but survival rates decreased progressively after 9-15 DAH from started day until completed metamorphosis stage in all treatments in all trials larvae rearing. Overall, initial average length of the larvae using in all trials larvae rearing was ranged from 2.70 to $2.75 \mathrm{~mm}$ (at age $4 \mathrm{DAH})$ among treatments, with no significant difference $(\mathrm{P} \leq 0.05)$. At the end of the trials have been larvae successfully completed metamorphosis.

\section{Larval development stages and metamorphosis stage}

There are five distinct line phases. These, can be related to the five different developmental stages of the larvae and post larvae. The first phase of wholly endogenous nutrition lasted for 3 days in all trials. At the first DAH, newly hatched larvae, symmetrical larvae with yolk sac and its tail flexure was retained, and the larvae swam in straight direction. The length of larvae was about $1.42 \mathrm{~mm}$. The yolk sac diameter was $1.0 \times 0.68 \mathrm{~mm}$ which contains oil globules ranged from 0.084 to $0.1 \mathrm{~mm}$. The eyes are not pigmented. The mouth not open and the larvae were endogenous feeding; it depends on the nutrients storage on the yolk sac. This was characterized by an initial rapid length increase prior to mouth opening and first feeding.

The second phase of transition from endogenous to exogenous nutrition occurred from 3-6 DAH. At age about 4 DAH, the total length was between 2.70 to $2.75 \mathrm{~mm}$. The mouth was opened and its jaws were developed. The eyes were more pigmented comparing to the previous stage. The yolk sac was reduced to less than one third its initial size $(0.20 \times 0.22 \mathrm{~mm})$. It was characterized by a retarded increase in length that coincided with depletion of yolk sac reserves. The third phase of accelerated growth occurred from about 8 DAH onward in fed larvae, and nutrition was entirely exogenous. The fourth stage of formation of caudal fin rays and ventral and dorsal fin rays extends from $10 \mathrm{DAH}$. The fifth, start of metamorphosis from 9-17 days and continued until metamorphosis is 
completed when the left eye transferred to right side of the head at about 16-36 DAH.

Metamorphosis in the eye and caudal fin when started, the larvae become asymmetric. The eye migration is beginning when the left eye is shifting to the dorsal midline of the head. The most representative stages of metamorphosis are when the left eye reaches the dorsal midline of the head; the larvae begin to change their swimming from vertical to benthic. Transparency of the body begins to reduce skin pigmentation intensifies. The left eye began to migrate to the other side, in accordance with the normal changes which take place in this species. At the age of 16-36 DAH, the larvae transformed symmetric floating larvae to asymmetric benthic juvenile. Both eyes now in the right side of the body and the juvenile assumes the benthic behavior typical of flatfishes. The pattern of pigmentation of sub-adult was becoming apparent. It becomes morphologically typical the adult one; a concentration of the pigment is distributed in all over the body in just one side of the flatfish (Fig.1). Metamorphosis was different according to the variability in salinity and temperature in the following trials larvae rearing.
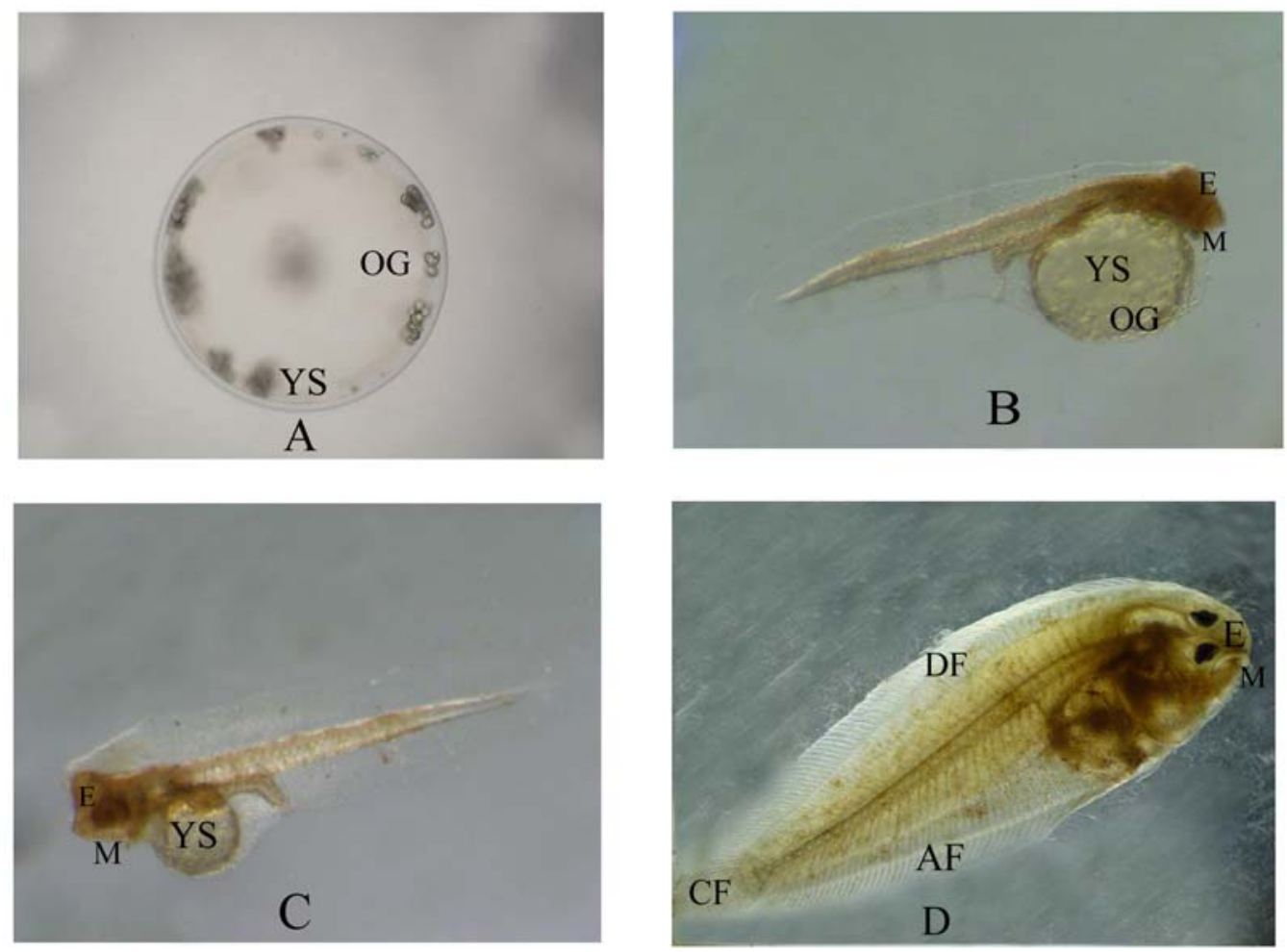

Fig. 1: Developmental stages of the Egyptian sole, Solea aegyptiaca larvae.

A). The fertilized egg, with the yolk sac (YS) and oil globules (OG).

B). The newly hatching larvae at the first DAH. It shows, eye is not pigmented (E). The mouth is not opened (M). The yolk sac (YS), with oil globules (OG), is very abundant and feeding is exclusively endogenous.

C). The larva at 4 (DAH). It shows, eyes are nearly pigmented (E). The mouth is opened (M). Larvae are feeding exogenous but some yolk sac (YS) is still remains.

D). The post-larvae at metamorphosis stage. It shows, dorsal fin (DF), caudal fin (CF) and anal fin (AF). Both eyes are on the right side of the body and the sole assumes the benthic behavior typical flatfish.

\section{Behavior of larvae}

Newly hatched larvae were buoyant at hatching for about 3-4 days. This is due to the presence of the yolk sac which contains oil globules. These larvae 
were grouped in the surface water layer and collected themselves in one location. After complete resorption of yolk sac and formation of pectoral fin on each sides of the trunk region of larvae that were easily swim up and down, and appear to be very flexible, bending their bodies in certain movement. At $15 \mathrm{DAH}$, the larvae started sinking to the bottom and sometimes, larvae may attach themselves on wall, also their flexibility began to decrease and lose. The larva was developed to complete metamorphosis and they were considered as bottom feeder and started to burrow into the sand.

The first experiment: Effect of salinity on growth performance, metamorphosis stage and survival rate

Results of growth performance, metamorphosis stage and survival rate for larvae reared in different salinity levels are present in Table (4). Survival rate values were relatively highest with larvae reared in $20 \%$, while the larvae under $30 \%$ o showed a lower survival rate, with significant differences $(\mathrm{P} \leq 0.05)$ were observed. The results showed that insignificant differences $(\mathrm{P} \leq 0.05)$ were obtained in all growth performance parameters between treatments. At the end of the trial (end of metamorphosis), average final weight and final length of larvae were 10.85, 9.55, $10.85,10.80,10.05 \mathrm{mg}$ and $10.05,9.20,10.50,10.50,9.50 \mathrm{~mm}$, for larvae reared in salinity $10,15,20,25$ and $30 \%$, respectively. Metamorphosis of the sampled speciemens were completed at 36.5, 34.5, 32.5, 34.0, 36.0 DAH for salinities 10,15, 20, 25 and 30\%, respectively. The results indicated that salinity (20\%) improved the growth rate of larvae without any statistical difference between treatments $(10,15,20,25$ and 30\%o) under experimental conditions.

Table 4: Effect of salinity on growth performance, metamorphosis stage and survival rate of the Egyptian sole, Solea aegyptiaca, larvae.

\begin{tabular}{|c|c|c|c|c|c|c|}
\hline \multirow[b]{2}{*}{ Items } & \multicolumn{5}{|c|}{ Salinity } & \multirow[b]{2}{*}{ SED* } \\
\hline & $10 \%$ & $15 \%$ & $20 \%$ & $25 \%$ & $30 \%$ & \\
\hline Initial aveg. Length, mm/larvae & 2.70 & 2.74 & 2.72 & 2.70 & 2.73 & 0.017 \\
\hline Final aveg. Length, mm/larvae & 10.05 & 9.20 & 10.50 & 10.50 & 9.50 & 1.057 \\
\hline Total length gain, $\mathrm{mm} /$ larvae & 7.35 & 6.47 & 7.78 & 7.80 & 6.77 & 1.065 \\
\hline Average daily length gain, $\mathrm{mm} /$ larvae/ day & 0.21 & 0.20 & 0.24 & 0.23 & 0.20 & 0.021 \\
\hline Final aveg. Weight, mg/larvae & 10.85 & 9.55 & 10.85 & 10.80 & 10.05 & 1.886 \\
\hline Condition factor, $\mathrm{mg} / \mathrm{mm}^{3}$ & 1.07 & 1.23 & 0.94 & 0.95 & 1.17 & 0.145 \\
\hline Metamorphosis stage, day & 36.5 & 34.5 & 32.5 & 34.0 & 36.0 & 2.258 \\
\hline Survival rate, $\%$ & $11.88^{\mathrm{b}}$ & $11.75^{\mathrm{bc}}$ & $12.80^{\mathrm{a}}$ & $11.25^{\mathrm{cd}}$ & $10.70^{\mathrm{d}}$ & 0.229 \\
\hline
\end{tabular}

- $(a, b, c)$ Average in the same row having different superscripts are differ significantly $(\mathrm{P} \leq 0.05)$.

* SED is the standard error of difference

\section{The second experiment: Effect of temperature on growth performance, metamorphosis stage and survival rate}

Results of growth performance, metamorphosis stage and survival rate for larvae reared in different water temperature are present in Table (5). Survival rate values were relatively highest with larvae reared in $16{ }^{\circ} \mathrm{C}$, while the larvae under temperature $\left(22^{\circ} \mathrm{C}\right.$ and $\left.23^{\circ} \mathrm{C}\right)$ showed a lower survival rate, with significant differences $(\mathrm{P} \leq 0.05)$ were observed. The results showed that significant differences $(\mathrm{P} \leq 0.05)$ were obtained in all growth performance parameters between treatments except the condition factor. Larvae exposed to different temperature showed differences in weight and length. The larvae under temperature $20{ }^{\circ} \mathrm{C}$ showed a highest growth rate during the experiment (which reached $14.50 \mathrm{~mm}$ in length, 32.85 $\mathrm{mg}$ in weight, complete metamorphosis at $22 \mathrm{DAH}$ ), while the larvae under temperature $16^{\circ} \mathrm{C}$ showed a lower growth rate during the experiment (which reached 
$9.50 \mathrm{~mm}$ in length, $11.25 \mathrm{mg}$ in weight, complete metamorphosis at $36 \mathrm{DAH}$ ). Significant differences at the end of metamorphosis were detected among treatments. The metamorphosis of group which reared under temperature 21,22 and $23{ }^{\circ} \mathrm{C}$ was the most fast in the other temperature, while larvae reared under temperature 16 and $17^{\circ} \mathrm{C}$ were the most slower in the other temperature. These results indicated that the best growth rate for larvae was obtained at temperature $20^{\circ} \mathrm{C}$, while the best survival rate was recorded at temperature $16{ }^{\circ} \mathrm{C}$ under experimental conditions. The growth rate for larvae has been increased gradually with increasing temperature until $20^{\circ} \mathrm{C}$ then decreased. Survival rate decreased gradually with increasing temperature.

Table 5: Effect of temperature on growth performance, metamorphosis stage and survival rate of the Egyptian sole, Solea aegyptiaca, larvae.

\begin{tabular}{|c|c|c|c|c|c|c|c|c|c|}
\hline \multirow[b]{2}{*}{ Items } & \multicolumn{8}{|c|}{ Temperature, ${ }^{\circ} \mathrm{C}$} & \multirow[b]{2}{*}{ SED* } \\
\hline & $16^{\circ} \mathrm{C}$ & $17^{\circ} \mathrm{C}$ & $18^{\circ} \mathrm{C}$ & $19^{\circ} \mathrm{C}$ & $20^{\circ} \mathrm{C}$ & $21^{\circ} \mathrm{C}$ & $22^{\circ} \mathrm{C}$ & $23^{\circ} \mathrm{C}$ & \\
\hline IL & 2.72 & 2.72 & 2.73 & 2.74 & 2.72 & 2.74 & 2.70 & 2.74 & 0.032 \\
\hline FL & $9.50^{b}$ & $10.50^{\mathrm{ab}}$ & $10.90^{\mathrm{ab}}$ & $11.20^{\mathrm{ab}}$ & $14.50^{\mathrm{a}}$ & $11.50^{\mathrm{ab}}$ & $10.50^{\mathrm{ab}}$ & $10.50^{\mathrm{ab}}$ & 1.489 \\
\hline TLG & $6.79^{\mathrm{b}}$ & $7.79^{\mathrm{ab}}$ & $8.17^{\mathrm{ab}}$ & $8.47^{\mathrm{ab}}$ & $11.78^{\mathrm{a}}$ & $8.77^{\mathrm{ab}}$ & $7.80^{\mathrm{ab}}$ & $7.77^{\mathrm{ab}}$ & 1.471 \\
\hline ADL & $0.19^{\mathrm{d}}$ & $0.22^{\mathrm{cd}}$ & $0.31^{\text {cd }}$ & $0.38^{\mathrm{bc}}$ & $0.54^{\mathrm{ab}}$ & $0.57^{\mathrm{a}}$ & $0.49^{\mathrm{ab}}$ & $0.51^{\mathrm{ab}}$ & 0.070 \\
\hline FW & $11.25^{\mathrm{b}}$ & $14.05^{\mathrm{b}}$ & $15.00^{\mathrm{b}}$ & $16.65^{b}$ & $32.85^{\mathrm{a}}$ & $17.75^{\mathrm{b}}$ & $11.50^{b}$ & $11.00^{\mathrm{b}}$ & 4.268 \\
\hline $\mathrm{K}$ & 1.31 & 1.24 & 1.15 & 1.19 & 1.09 & 1.16 & 0.99 & 0.96 & 0.187 \\
\hline Meta. & $36.0^{\mathrm{a}}$ & $36.5^{\mathrm{a}}$ & $26.5^{\mathrm{b}}$ & $22.0^{\mathrm{c}}$ & $22.0^{c}$ & $15.5^{\mathrm{d}}$ & $16.0^{\mathrm{d}}$ & $15.5^{\mathrm{d}}$ & 1.118 \\
\hline $\mathrm{SR}, \%$ & $11.75^{\mathrm{a}}$ & $10.65^{b}$ & $8.55^{\mathrm{c}}$ & $7.43^{\mathrm{d}}$ & $7.40^{\mathrm{d}}$ & $7.13^{\mathrm{d}}$ & $7.08^{\mathrm{d}}$ & $7.05^{\mathrm{d}}$ & 0.372 \\
\hline
\end{tabular}

- $(\mathrm{a}, \mathrm{b}, \mathrm{c})$ Average in the same row having different superscripts are differ significantly $(\mathrm{P} \leq 0.05)$.

SED is the standard error of difference

IL- Initial aveg. Length, mm/larvae, Fl- Final aveg. Length, mm/larvae, TLG-Total length gain, $\mathrm{mm} /$ larvae, ADL- Average daily length gain, mm/ larvae/ day, FW- Final aveg. Weight, mg/larvae, KCondition factor, $\mathrm{mg} / \mathrm{mm}^{3}$, Meta.- Metamorphosis stage, day, SR, \% - Survival rate, \%

\section{The third experiment: Effect of feed type on growth performance and survival rate of weaning post-larvae}

Results of growth performance parameters and survival rate of Solea aegyptiaca post-larvae fed on the different feed are shown in Table (7). There was no significant difference in the initial average length and weight of the post-larvae among treatments.

Table 7: Effect of feed type on growth performance and survival rate of weaning post-larvae of the Egyptian sole, Solea aegyptiaca.

\begin{tabular}{|l|c|c|c|c|}
\hline \multirow{2}{*}{ Items } & \multicolumn{2}{c|}{ Feed type } & \multirow{2}{*}{ SED* } \\
\cline { 2 - 4 } & $\mathbf{T}_{\mathbf{1}}$ & $\mathbf{T}_{\mathbf{2}}$ & $\mathbf{T}_{\mathbf{3}}$ & \\
\hline Initial aveg. Length, mm/larvae & 10.50 & 10.50 & 10.00 & 1.527 \\
\hline Final aveg. Length, mm/larvae & $47.50^{\mathrm{a}}$ & $35.50^{\mathrm{b}}$ & $25.00^{\mathrm{c}}$ & 3.317 \\
\hline Initial aveg. Weight, mg/fish & 11.50 & 11.60 & 11.30 & 0.757 \\
\hline Final aveg. Weight, mg/fish & $663.50^{\mathrm{a}}$ & $255.00^{\mathrm{b}}$ & $111.50^{\mathrm{c}}$ & 25.357 \\
\hline Total weight gain, mg/fish & $652.00^{\mathrm{a}}$ & $243.40^{\mathrm{b}}$ & $100.20^{\mathrm{c}}$ & 24.774 \\
\hline Average daily weight gain, mg/fish /day & $6.52^{\mathrm{a}}$ & $2.43^{\mathrm{b}}$ & $1.00^{\mathrm{c}}$ & 0.247 \\
\hline Specific growth rate (SGR), \%/day & $4.06^{\mathrm{a}}$ & $3.09^{\mathrm{b}}$ & $2.26^{\mathrm{c}}$ & 0.182 \\
\hline Condition factor, mg/mm ${ }^{3}$ & 0.62 & 0.60 & 0.70 & 0.130 \\
\hline Survival rate, \% & $76.93^{\mathrm{a}}$ & $73.08^{\mathrm{a}}$ & $34.62^{\mathrm{b}}$ & 7.693 \\
\hline
\end{tabular}

- $(a, b, c)$ Average in the same row having different superscripts are differ significantly $(\mathrm{P} \leq 0.05)$.

* SED is the standard error of difference

Post-larvae fed on different feeds showed significant differences $(\mathrm{P} \leq 0.05)$ in survival rate between treatments; post-larvae fed on (Artemia $\left(\mathrm{T}_{1}\right)$ and Artemia + artificial feed $\left(\mathrm{T}_{2}\right)$ ) led to higher survival compared to fed on artificial feed $\left(\mathrm{T}_{3}\right)$. 
The results showed that significant differences $(\mathrm{P} \leq 0.05)$ were obtained in all growth performance parameters between treatments, except the condition factor. Results of growth performance parameters were highest with fed on $T_{1}$ compared to the other feeds $\left(\mathrm{T}_{2}\right.$ and $\left.\mathrm{T}_{3}\right)$. Results show that final length $(\mathrm{mm})$, final weight $(\mathrm{mg})$, SGR (\%) and survival rates (\%) for feeding on $\mathrm{T}_{1}, \mathrm{~T}_{2}$ and $\mathrm{T}_{3}$ were $(47.50,35.50$, $25.00 \mathrm{~mm}),(663.50,255.00,111.50 \mathrm{mg}),(4.06,3.09,2.26 \%)$ and $(76.93,73.08$, $34.62 \%)$, respectively. These results indicated that the best growth rate for postlarvae was obtained at feeding on Artemia then feeding on Artemia + artificial feed under experimental conditions. Post-larvae fed Artemia showed statistically higher growth comparing to all the other groups.

\section{DISCUSSION}

Generally, in the present trials the larval survival rates (7-12.80\%) were lower than range survival rates in the previous studies; (74.5-81\%) for Solea senegalensis (Canavate et al., 2006), 44-65\% for Solea senegalensis (Salas-Leiton et al., 2012), 43-56\% for Solea solea (Bonaldo et al., 2011), 40\% for Solea solea (Palazzi et al., 2006). This may be attributed to pollution by coliform bacteria in the water source Lake Qaroun (total coliforms 190, fecal coliforms 140, fecal streptococci 260/100 $\mathrm{ml}$ ). Also, it may be related to differences in larval rearing conditions.

Nutritional unbalance (Gisbert et al., 2008) and environmental conditions such as pollution (Sun et al., 2009), extreme temperature (Okamura et al., 2007) and physical stress (Morrison and Mac-Donald, 1995) have been reported as likely causing jaw deformities. Abnormalities in jaw development, and the resulting inability to feed (Morrison and Mac-Donald, 1995) which may affect the overall larval survival. From previous studies the survival rate of larvae depends on environmental conditions such as photoperiods, light intensity, salinity, temperature, stocking density, feed quality, feeding regime, rearing system (aeration and water exchange), tank size and tank colour.

The metamorphosis in flatfish is related to the change from the pelagic to benthic habitat, and it implies important changes in fish physiology (Fernandez-Diaz et al., 2001). The transformation occurs at a wide range of sizes depending on species and environmental circumstances (Policansky, 1982; Ottesen and Bolla, 1998). Whether age or size is key factors in starting metamorphosis is a question that has been considered in several studies with other species, such as Atlantic halibut larvae (Ottesen and Bolla, 1998). In addition, this question is important in laboratory populations in which growth and therefore, the size of larvae and successful metamorphosis depend on the rearing conditions (Fernandez-Diaz et al., 2001). Parameters such as stocking density, salinity, temperature, feeding or light have been observed to affect the development and metamorphosis process in flatfish (Bolla and Holmefjord, 1988; Daniels et al., 1996).

\section{Effect of salinity}

The possibility of successfully rearing sole larvae under reduced salinity conditions would lead to new options for hatchery facilities where only brackish water is available. In the present study, the following five salinities $(10,15,20,25$ and 30\%o) were tested on Solea aegyptiaca larvae and found no significant difference in growth, but the best performance of larvae was at salinity 20\%o. These results similar to that of Salas-Leiton et al. (2012) who reported that larval rearing until complete metamorphosis under standard culture conditions demonstrated that Solea senegalensis larvae could be successfully reared at $10 \%$ if transference to 
this low salinity is carried out once the mouth opening process has been completed (2-3 DAH). They added no significant differences were found between salinities of 10 and 33\%o when feeding activity was analysed in the first six rearing days. Both salinities led to similar individual dry weights throughout the experimental period, with significantly higher weights recorded in larvae grown at $10 \%$ salinity only at $21 \mathrm{DAH}$. With the exception of $14 \mathrm{DAH}$, the higher weight achieved at $21 \mathrm{DAH}$ in our larvae reared at $10 \%$ salinity is probably associated with decreased survival, and consequently with lower stocking densities during the last days of metamorphosis (Salas-Leiton et al., 2012). Also, similar results in the flatfish European flounder (Platichthys flesus) were obtained by O'Neill et al. (2011) who found that, no significant difference in ontogenetic development between exposures (salinity of $0,10,20$ and $30 \%$ ). No significant differences in somatic growth rate, somatic condition or standard length were observed between treatments.

The relationship between salinity and growth rate throughout the larval stages in the flatfish, both Brazilian and greenback flounders showed optimum growth over salinities ranging from 20 to 30\%o (Sampaio et al., 2007) and from 15 to $35 \%$, respectively (Hart et al., 1996). The spotted halibut (Verasper variegatus) preferred moderately low salinities (8-16\%) during the larva-juvenile transformation period (Wada et al., 2004). Turbot inhabiting the North Sea had optimum rates at salinities above 20\%o (Karas and Klingsheim, 1997).

The results of the current study, showed that under experimental conditions of salinity, there were insignificant differences between treatments in the development of metamorphosis, a process completed 32.5-36.5 DAH under different salinities. Similar results were obtained by Salas-Leiton et al. (2012) who showed that, salinity did not induce differences in the development of metamorphosis between 10 and 33\%o salinity, but a process completed 21 DAH under both salinities for Solea senegalensis.

In this study, survival rate values were relatively highest with larvae reared in $20 \%$, while the larvae under $30 \%$ showed a lower survival rate, with significant differences between different salinities. Similarly, Moustakas et al., (2004) found that, larvae of southern flounder (Paralichtys lethostigma) showed reduced survival and markedly lower growth rates at full-strength seawater (35\%) compared to that achieved at a lower salinity (25\%) from hatching to 15 DAH. Also, Kerstan (1991) found that within estuaries, densities of juvenile $P$. flesus significantly increased with decreasing salinity. On the other hand, a higher final survival rate was obtained in Solea senegalensis larvae cultivated at 33\% compared to $10 \%$ salinity (Salas-Leiton et al., 2012). Also, lower survival rates were obtained in greenback flounder larvae reared at $15 \%$ salinity in comparison to either 25 or 35\% (Hart et al., 1996). Moreover, Salas-Leiton et al. (2012) found that, newly hatched and early-developing yolk sac larvae presented similar survival rates 3 DAH when exposed to salinities of $10,18,27$ and 33\%, one noticeable finding was the diverse jaw abnormalities (affecting $100 \%$ of larvae) and the subsequent ingestion inability associated with a salinity of $10 \%$.

The results of the present study indicated that, Solea aegyptiaca might be successfully developed until metamorphosis over the range 10-30\%, and the ability of Solea aegyptiaca larvae to grow over a wide salinity range previously. Our overall results demonstrated that Solea aegyptiaca larvae have the capacity to be successfully reared following standard procedures at salinities as low as $10 \%$, with the only requisite being completed mouth development before transference to 
low salinity. That is, larvae can be kept in incubators at medium or high salinity $(\geq 18 \%$ ) until $2 \mathrm{DAH}$ and then transferred to rearing tanks recommended by SalasLeiton et al. (2012) for Solea senegalensis. Spontaneous activity and swimming behaviour (Boeuf and Payan, 2001) as well as food consumption, digestion and absorption of prey can be altered under different salinity regimes (Jobling, 1994; Boeuf and Payan, 2001). These processes can affect energy expenditure and consequentey fish condition (O'Neill et al., 2011).

\section{Effect of temperature}

Temperature represents the most important environmental factor that drive development, growth, and survival of marine fish during their early life history (Pepin, 1991). In the present study, eight different temperatures $(16,17,18,19,20$, 21,22 and $23^{\circ} \mathrm{C}$ ) were tested for Solea aegyptiaca larvae. The larvae under temperature $20^{\circ} \mathrm{C}$ showed the highest growth rate, while the larvae under temperature $16{ }^{\circ} \mathrm{C}$ showed the lower growth rate during the experiment. The growth rate for larvae has been increased gradually with increasing temperature until $20^{\circ} \mathrm{C}$ then decreased. These results agreed with most studies on biological development and temperature in Senegal sole as many authors have used a constant temperature of $20^{\circ} \mathrm{C}$ (Martinez et al., 1999; Parra and Yufera, 1999; Ribeiro et al., 1999; Yufera et al., 1999; Canavate et al., 2006; Sanchez et al., 2010; Salas-Leiton et al., 2011, 2012). The Senegal sole (Solea senegalensis) is a flatfish adapted to temperate waters of around $20-21^{\circ} \mathrm{C}$ (Drake et al., 1984).

On the other hand, Blanco-Vives et al. (2010) reported that, Solea senegalensis larvae were exposed to constant temperature $\left(20.7^{\circ} \mathrm{C}\right), 22.1^{\circ} \mathrm{C}$ day: $19.0^{\circ} \mathrm{C}$ night and $19.2^{\circ} \mathrm{C}$ day: $22.0^{\circ} \mathrm{C}$ night. The sole larvae achieved the best growth performance, and fastest development under thermocycle conditions $\left(22.1^{\circ} \mathrm{C}\right.$ day: $19.0^{\circ} \mathrm{C}$ night $)$. Larvae under $\left(19^{\circ} \mathrm{C}\right.$ day $/ 22^{\circ} \mathrm{C}$ night $)$ showed lower growth than those under the other treatments. In addition, Palazzi et al. (2006) recorded that, growth rate of S. solea reached the maximum incremental rate between 20 and $25^{\circ} \mathrm{C}$. Also, Irvin (1973) studied rearing of $S$. solea juvenile at five temperatures ranging from 11 to $27^{\circ} \mathrm{C}$ for 12 weeks. The fish showed an approximately linear increase in growth from 9 to 23 ${ }^{\circ} \mathrm{C}$ and a drop in growth after that. Fonds (1976) studied also rearing of S. solea juvenile at temperatures ranging from 10 to $25^{\circ} \mathrm{C}$ for over a year. In his study he found that the fish grew slower as they were larger than the fish in Irvin's (1973) study, but both experiments showed little increase in growth rates above $20{ }^{\circ} \mathrm{C}$ and indicated that the optimum temperature for growth was between 20 and $25^{\circ} \mathrm{C}$. Yolk utilization efficiency decreases towards the limits of a species range of temperature tolerance (Heming and Buddington, 1988). Development of sole eggs succeed at temperature ranged from 7 to $19^{\circ} \mathrm{C}$, while, larval growth of sole was lower than that ranged from 10 to $23{ }^{\circ} \mathrm{C}$ (Fonds, 1979).

The results of the current study, showed a significant differences in completion of metamorphosis at $36,36.5,26.5,22,22,15.5,16$ and 15.5 DAH for temperature $16,17,18,19,20,21,22$ and $23^{\circ} \mathrm{C}$, respectively. Similar results were obtained by Zaki et al. (1998) showed that, metamorphosis of Solea aegyptiaca was completed at $18 \mathrm{DAH}$ at $21.5^{\circ} \mathrm{C}$. Also, similar results on Solea solea were reported by Palazzi et al. (2006) and Lund et al. (2007) showed that, metamorphosis was completed at $25 \mathrm{DAH}$ at $18{ }^{\circ} \mathrm{C}$. Also, Blanco-Vives et al. (2010) showed that, metamorphosis of Solea senegalensis was completed at 17 DAH at $\left(22.1{ }^{\circ} \mathrm{C}\right.$ day: $19.0^{\circ} \mathrm{C}$ night). Larvae reared under constant temperature $(20.7$ $\left.{ }^{\circ} \mathrm{C}\right)$ completed the metamorphosis at $17 \mathrm{DAH}$, while larvae exposed to $\left(19{ }^{\circ} \mathrm{C}\right.$ day/22 ${ }^{\circ} \mathrm{C}$ night) completed at 19 DAH. Contrarily, Zaki et al. (1998) showed that, 
metamorphosis of Solea aegyptiaca was completed at 27 and 29 DAH at 20 and $15{ }^{\circ} \mathrm{C}$, respectively. Also, Bonaldo et al. (2011) showed that, metamorphosis of Solea solea was completed at $33 \mathrm{DAH}$ at $18{ }^{\circ} \mathrm{C}$. Also, Dinis et al. $(1996,1999)$ showed that, metamorphosis of S. senegalensis was completed at $19 \mathrm{DAH}$ at 18 ${ }^{\circ} \mathrm{C}$. As well as, Yufera et al. (1999) reared larvae of S. senegalensis until the end of metamorphosis at $17 \mathrm{DAH}$ at $19.5^{\circ} \mathrm{C}$.

In this study, survival rate values were relatively highest with larvae reared in $16^{\circ} \mathrm{C}$, while the larvae under temperature $\left(22^{\circ} \mathrm{C}\right.$ and $\left.23^{\circ} \mathrm{C}\right)$ showed a lower survival rate. Survival rate decreased gradually with increasing temperature. Similar results on Solea aegyptiaca were reported by Zaki et al. (1998) as survival rate through embryonic developmental stages were $83.3 \%$ at $15{ }^{\circ} \mathrm{C}, 83 \%$ at $16{ }^{\circ} \mathrm{C}, 82 \%$ at $20^{\circ} \mathrm{C}$, survival rate was little decreased with increasing temperature. Also, Fonds (1979) incubated sole eggs at five different temperatures between 10 and $22^{\circ} \mathrm{C}$, high survival and normal development until hatching were observed at temperatures from 10 to 16 ${ }^{\circ} \mathrm{C}$. On the other hand, the results disagree with data obtained by Blanco-Vives et al. (2010) reported that, Solea senegalensis larvae were exposed to constant temperature $\left(20.7^{\circ} \mathrm{C}\right), 22.1{ }^{\circ} \mathrm{C}$ day: $19.0^{\circ} \mathrm{C}$ night and $19.2^{\circ} \mathrm{C}$ day: $22.0^{\circ} \mathrm{C}$ night. The sole larvae achieved the best survival under thermocycle conditions $\left(22.1{ }^{\circ} \mathrm{C}\right.$ day: $19.0{ }^{\circ} \mathrm{C}$ night $)$.

Temperature has long been reported to influence the growth, survival and development of fish larvae both in the wild and laboratory (Methot and Kramer, 1979; Pepin, 1991; Green and Fisher, 2004; Johnston et al., 2004). In flatfish larvae the environmental factors may be crucial in determining recruitment to nursery grounds via their effects on growth and mortality during the metamorphosis-settlement period (Yamashita et al., 2001). Some studies have demonstrated the existence of daily rhythms of temperature selection in fish in wild conditions. In such studies, fish showed daily migrations as they searched for a preferred temperature for physiological activity and growth (Gibson et al., 1998; Sims et al., 2006). Ottesen and Bolla (1998) reported that some physical parameters, including inappropriate temperature or salinity; may be associated with jaw malformation due to mechanical damage in cultured larvae. The temperature in water undergoes changes according to the climatic fluctuations (Chapman and Kimstach, 1996). Surface water temperatures are affected by many different factors; season, altitude, latitude, time of day, cloud cover, air circulation and depth and flow of the body of water. Furthermore, fish are more susceptible to disease at extreme temperatures (Holt et al., 1975). Provided that food availability is unrestricted, metabolic rate increases as temperature increases. Growth is found to decrease at temperatures above the optimum because of a possible decrease in appetite and high energy cost of maintenance metabolism (Jobling, 1994). At low temperatures, growth is restricted because of low metabolic rates and low food intake. Hence, when culturing a species, best performance is obtained when temperatures are optimal.

\section{Effect of feed type on weaning post-larvae}

Weaning and metamorphosis which are accompanied by increased mortality rates (Rueda-Jasso et al., 2005). The utilization of a co-feeding regimen, which gradually weans larvae off live preys has been able to promote digestive maturation at early age (Engrola et al., 2007, 2009) and to improve growth performances and survival rate of marine fish larvae (Rosenlund et al., 1997). A precocious substitution of live feed with micro-diets could promote the early adaptation of larvae to dry feed (Gatesoupe and Luquet, 1982). In previous studies on sole weaning, weaning was considered the major obstacle to sole rearing and several attempts were made to obtain suitable weaning diets (Bromley, 
1977; Metailler et al., 1981; Appelbaum, 1985; Canavate and Fernandez-Diaz, 1999), focusing on the chemical substances acting as feeding stimulants (Mackie et al., 1980; Cadena-Roa et al., 1982; Metailler et al., 1983). Diet palatability and digestibility both appear to be critical aspects in sole weaning. According to Gatesoupe and Luquet (1982) there is a choice to be made between two ways of weaning (i.e., Artemia for 25 days (Fuchs, 1978) or Artemia for 5-15 days supplemented with an artificial diet (Gatesoupe and Luquet, 1982). The first one gives higher growth rate but also high costs (due do Artemia expenses), and the second alternative is less costly but yields lower growth. In the study conducted by Villalta et al. (2005), larvae of Senegal sole fed on the diet containing the highest docosaesaenoic acid (DHA) concentration, had the lowest growth in length comparing to the other groups.

In the present study, three different feed: (Artemia, Artemia + artificial feed and artificial feed) of weaning Solea aegyptiaca post-larvae were tested. Results of growth performance parameters were highest with post-larvae fed on Artemia compared to the other feeds (Artemia + artificial feed and artificial feed). Larvae fed on (Artemia and Artemia + artificial feed) led to higher survival compared to that fed on artificial feed. These results agreed with the findings of Bonaldo et al. (2011) who tested different weaning strategies on Solea solea using the commercial micro-diets, they obtained a very early weaning using commercial micro-diets in common sole larvae affects growth performance but no statistical differences among groups were observed in survival rates with better survival rate in control (fed on Artemia). Also, Koven et al. (2001) reported that, the poor performance of Sea bream larvae exclusively fed on micro-diets is related to the variable acceptance and attraction of the inert particle compounded by inadequate ingestion, digestion and assimilation. Physico-chemical characteristics of micro-diets such as color, shape, particle size, sedimentation rate or release of attractants can influence feed intake by very young fish (Saenz de Rodriganez et al., 2011). In addition, larvae have to be able to digest the particles and be able to absorb and assimilate the nutrients that must fit the requirement of the larvae (Kvale et al., 2006).

On the other hand, Palazzi et al. (2006) Carried out, three weaning trials for Solea solea comparing two commercial feeds on larvae about $30 \mathrm{DAH}$. One of these feeds was sufficient in itself to complete juvenile weaning, reaching average survival rates of $85 \%$, which are comparable to those obtained in the control groups fed on live Artemia. Average survival rates of $43 \%$ were obtained with the second commercial feed. Both commercial feeds enabled superior juvenile growth on average to that in the control groups. Also, Engrola et al. (2007) tested different weaning strategies on Senegal sole (Solea senegalensis) using the commercial micro-diets. They obtained that survival rates were not exceeding $40 \%$ at 26 and $33 \mathrm{DAH}$, but up to $90 \%$ when larvae were weaned at 40 and 60 DAH. In addition, studies (Howell, 1998; Day et al., 1999) have demonstrated that young sole can be weaned on to commercially prepared formulated feeds with high survival and growth approaching those attainable on live foods.

In the present study, Solea aegyptiaca larvae fed on Artemia led to higher growth and survival compared to fed on artificial feed only might be related to the following: Live feeds (as Artemia) are able to swim in the water column and are thus constantly available to the larvae. Formulated diets tend to aggregate on the water surface or, more commonly, sink quickly to the bottom, and are thus normally less available to the larvae than are the live feeds. In addition, the movement of live feed 
in the water is likely to stimulate larval feeding responses, since evolutionary history has probably adapted them to attack moving prey in nature. Formulated diets are generally capable of moving only in a downward direction, towards the bottom. Finally, live prey, with a thin exoskeleton and high water content, may be more palatable to the larvae once taken into the mouth, compared to the hard, dry formulated diets. Any food must enter the mouth whole (i.e. the larva's mouth gape must be of sufficient size for particle ingestion to occur) and they are quickly either accepted or rejected on the basis of palatability.

In conclusion, from the results of the present study, the best performance and survival rate of larvae is at salinity $20 \%$. The larvae under water temperature $20^{\circ} \mathrm{C}$ showed a highest growth rate, where growth has been increased gradually with increasing temperature until $20^{\circ} \mathrm{C}$ then decreased, while survival rate decreased gradually with increasing temperature. The best feed for post-larvae weaning is Artemia only under experimental conditions. So, it is recommended to Solea aegyptiaca larval rearing under salinity (20\%). Reared of larvae under temperature $16-17^{\circ} \mathrm{C}$ from $1 \mathrm{DAH}$ to metamorphosis stage, because of its high survival rate at this temperature, then rearing under temperature $20^{\circ} \mathrm{C}$ from metamorphosis stage to onward, because of its high growth rate at this temperature, and feeding on Artemia for post-larvae weaning.

\section{REFERENCES}

Allen, P. J. and Chec, J.J. (2007). Age/size effects on juvenile green sturgeon, Acipenser medirostris, oxygen consumption, growth and osmoregulation in saline environments. Environ. Biol. Fishes, 79: 211-229.

Anguis, V. and Canavate, J. P. (2005). Spawning of captive Senegal sole (Solea senegalensis) under a naturally fluctuating temperature regime. Aquaculture, 243: 133-145.

APHA (1992). Standard methods for the examination of water and waste, 18th ed. American Public Health Association, Washington DC. 1268 pp.

Appelbaum, S. (1985). Rearing of the Dover sole, Solea solea (L), through its larval stages using artificial diets. Aquaculture, 49: 209-221.

Blanco-Vives, B.; Villamizer, N.; Ramos, J.; Bayarri, M.J.; Chereguini, O. and Sanchez-Vazquez, F.J. (2010). Effect of deily thermo-and photo-cycles of different light spectrum on the development of Senegal sole (Solea senegalensis) larvae. Aquaculture, 306: 137-145.

Boeuf, G. and Payan, P. (2001). How should salinity influence fish growth? Comp. Biochem. Physiol., 130(C): 411-423.

Bolla, S. and Holmefjord, I. (1988). Effect of temperature and light on development of Atlantic halibut larvae. Aquaculture, 74: 355-358.

Bonaldo, A.; Parma, L.; Badiani, A.; Serratore, P. and Gatta, P.P. (2011). Very early weaning of common sole (Solea solea L.) larvae by means of different feeding regimes and three commercial microdiets: Influence on performances, metamorphosis development and tank hygiene. Aquaculture, 321: 237-244.

Bromley, P.J. (1977). Methods of weaning juvenile hatchery reared sole (Solea solea (L.)) from live food to prepared diets. Aquaculture, 12: 337-347.

Cadena-Roa, M.; Huelvan, C.; Le Borgne, Y. and Metailler, R. (1982). Use of rehydratable extruded pellets and attractive substances for the weaning of sole (Solea vulgaris). J. World Maric. Soc., 13: 246-253. 
Callan, C.; Jordaan, A. and Kling, L.J. (2003). Reducing Artemia use in the culture of Atlantic cod (Gadus morhua). Aquaculture, 219: 585-595.

Canavate, J.P. and Fernandez-Diaz, C. (1999). Influence of larval co-feeding on live and inert diets in the weaning of the sole Solea senegalensis onto commercial dry feeds. Aquaculture, 174: 255-263.

Canavate, J.C.; Zerolo, R. and Fernandez-Diaz, C. (2006). Feeding and development of Senegal sole (Solea senegalensis) larvae reared in different photoperiods. Aquaculture, 258: 368-377.

Cardona, L. (2000). Effects of salinity on the habitat selection and growth performance of Mediterranean flathead grey mullet Mugil cephalus (Osteichthyes, Mugilidae). Estuarine Coastal Shelf Sci., 50: 727-737.

Chapman, D. and Kimstach, V. (1996). Selection of water quality variables. In: water quality assessments - a guide to the use of biota, sediments and water in environmental monitoring. E and FN Spon, Chapman and Hall. London, UK. pp. 59-126.

Daniels, H.V.; Berlinsky, D.L.; Hodson, R.G. and Sullivan, C.V. (1996). Effects of stocking density, salinity, and light intensity on growth and survival of Southern flounder Paralichthys lethostigma larvae. J. World Aquacul. Soc., 27: 153-159.

Day, O.J.; Howell, B.R.; Aksnes, A. and Nygard, E. (1999). Recent advances in the weaning of sole, Solea solea (L.). In: Abstracts of contributions presented at the International Conference Aquaculture Europe 1999. Special Publication no. 27. European Aquaculture Society, pp. 40-41.

Deacon, N. and Hecht, T. (1999). The effects of reduced salinity on growth, food conversion and protein efficiency ratio in juvenile spotted grunter, Pomadasys commersonnii (Lacepede) (Teleostei: Haemulidae). Aquac. Res., 30: 13-20.

Dinis, M.T. (1992). Aspects of the potential of Solea senegalensis Kaup for aquaculture: Larval rearing and weaning to artificial diets. Aquac. Fish. Manage., 23: 515-520.

Dinis, M.T. and Reis, J. (1995). Culture of Solea sp. 'Workshop on Diversification in Aquaculture' Cyprus June. Cahiers Options Mediterranees, 16: 1-7.

Dinis, M.T.; Reis, J. and Arrobas, J. (1996). Evaluation of the farming potential for Solea senegalensis Kaup, a new species for aquaculture in the Mediterranean area. In: Book of Abstracts World Aquaculture 1996, Bangkok, pp. 107-109.

Dinis, M.T.; Ribeiro, L.; Soares, F. and Sarasquete, C. (1999). A review on the cultivation potential of Solea senegalensis in Spain and in Portugal. Aquaculture, 176: 27-38.

Drake, P.; Arias, A.M. and Rodriguez, R.B. (1984). Cultivo extensivo de peces marinos en los esteros de las salinas de San Fernando (Cadiz). II. Caracteristicas de la produccion de peces. Informes tecnicos de investigacion pesquera. 116, $23 \mathrm{pp}$.

Engrola, S.; Conceicao, L.E.C.; Dias, L.; Pereira, R.; Ribeiro, L. and Dinis, M.T. (2007). Improving weaning strategies for Senegalese sole: effects of body weight and digestive capacity. Aquaculture Research, 38: 696-707.

Engrole, S.; Figueira, L.; Conceicao, L.E.C.; Gavaia, P.J.; Ribeiro, L. and Dinis, M.T. (2009). Co-feeding in Senegalese sole larvae with inert diet from mouth opening promotes growth at weaning. Aquaculture, 288: 264-272.

EPA (1983). Methods for chemical analysis of water and wastes. Cincinnati OH, SA: US Environmental Protection Agency 45268: (EPA-600/4-79-020). 
Fernandez-Diaz, C.; Yufera, M.; Canavate, J.P.; Moyano, F.J.; Alarcon, F.J. and Diaz, M. (2001). Growth and physiological changes during metamorphosis of Senegal sole reared in the laboratory. J. Fish Biol., 58: 1086-1097.

Fonds, M. (1976). The influence of temperature and salinity on growth of young sole Solea solea L. 10th Eur. Symp. Mar. Biol., 1: 109-125.

Fonds, M. (1979). Laboratory observations on the influence of temperature and salinity on development of the eggs and growth of the larvae of Solea solea (Pisces). Mar. Ecol. Prog. Ser., 1: 91-99.

Fuchs, J. (1978). Effect of photoperiod on growth and survival during rearing of larvae and juveniles of sole (Solea solea). Aquaculture, 15: 63-74.

Gatesoupe, F.J. and Luquet, P. (1982). Weaning of the sole (Solea solea) before metamorphosis. Aquaculture, 26: 359-368.

Gibson, R.N.; Pihl, L.; Burrows, M.T.; Modin, J.; Wennhage, H. and Nickell, L.A. (1998). Diel movements of juvenile plaice Pleuronectes platessa in relation to predators, competitors, food availability and abiotic factors ona microtidal nursery ground. Mar. Ecol. Prog. Ser., 165: 145-159.

Gisbert, E.; Fernandez, I. and Estevez, A. (2008). Avances en nutricion acuicola. In: Cruz-Suarez, L.E.; Ricque-Marie, D.; Tapia-Salazar, M.; Nieto- Lopez, M.G.; Villareal-Cavazos, D.A.; Lazo, J.P. and Viana, M.T. (eds) Nutricion y Morfogenesis: Efecto de la Dieta Sobre la Calidad Larvaria en Peces, pp. 46-78. Proceedings of the IX International Symposium on Aquaculture Nutrition, University of Nuevo Leon, Monterrey, Nuevo Leon, Mexico.

Green, B.S. and Fisher, R. (2004). Temperature influences swimming speed, growth and larval duration in coral reef fish larvae. J. Exp. Mar. Biol. Ecol., 299: 115132.

Hart, P.R.; Hutchinson, W.G. and Purser, G.J. (1996). Effects of photoperiod, temperature and salinity on hatchery-reared larvae of the greenback flounder (Rhombosolea tapirina Gunther, 1862). Aquaculture, 144: 303-311.

Heming, T.A. and Buddington, R.K. (1988). Yolk absorption in embryonic and larval fishes. In, Fish Physiology, Vol. II: The physiology of developing fish. Part A Eggs and larvae, edited by Hoar, W.S. and Randall, D.J. Academic Press, San Diego, CA, pp. 407-446.

Holt, R.A.; Sanders, J.L.Z.; Fryer, L.L. and Pilcher, K.S. (1975). Relation of water temperature to Flexibacter columnaris infection in steelhead trout (Salmo gairdneri), coho salmon (Oncorhynchus kisutch) and chinhook (O. tshawytscha) salmon. Journal of the Fisheries Research Board of Canada, 32:1553-1559.

Howell, B.R. (1998). The effect of stocking density on growth and size variation in cultured turbot, Scophthalmus maximus, and sole Solea solea. ICES CM 1998/L:10.

Hutchinson, S. and Hawkins, L.E. (1990). The influence of salinity on water balance in 0-group flounders, Platichthys flesus (L). J. Fish Biol., 36:751-764.

Irvin, D.N. (1973). The growth and survival of Dover sole, Solea solea, and some observations on the growth of the plaice Pleuronectes platessa, considered at various temperatures. $\mathrm{PhD}$ thesis, University of Liverpool, $186 \mathrm{pp}$.

Jobling, M. (1994). Fish Bioenergetics. Chapman and Hall, London, UK, 309 pp.

Johnston, I.A.; Hall, T.E. and Govoni, J.J. (2004). Mechanisms of muscle development and responses to temperature change in fish larvae. Development of form and function in fishes and the question of larval adaptation. Am. Fish Soc. Symp., 40: 85-116. 
Karas, P. and Klingsheim, V. (1997). Effects of temperature and salinity on embryonic development of turbot (Scophthalmus maximus L.) from the North Sea, and comparisons with Baltic populations. Helgolander Meeresunters, 51: 241-247.

Kariman, A.S. (2009). Some observation on fisheries biology of Tilapia zillii (Gervais, 1884) and Solea vulgaris (Quensel, 1806 in lake Qarun, Egypt. World Journal of Fish and Mar. Sci., 1: 20-28.

Kerstan, M. (1991). The importance of rivers as nursery grounds for 0 - and $1+$ group flounder (Platichthys flesus L.) in comparison to the Wadden Sea. Neth. J. Sea Res., 27 (3/4): 353-366.

Klaren, P.H.M.; Wunderink, Y.S.; Yufera, M.; Mancera, J. M. and Flik, G. (2008). The thyroid gland and thyroid hormones in Senegalese sole (Solea senegalensis) during early development and metamorphosis. General and Comparative Endocrinology, 155: 686-694.

Koven, W.; Kolkovski, S.; Hadas, E.; Gamsiz, K. and Tandler, A. (2001). Advances in the development of microdiets for gilthead sea bream, Sparus aurata: a review. Aquaculture, 194: 107-121.

Kvale, A.; Yufera, M.; Nygard, E.; Aursland, K.; Harboe, T. and Hamre, K. (2006). Leaching properties of three different micropaticulate diets and preference of the diets in cod (Gadus morhua L.) larvae. Aquaculture, 251: 402-415.

Likongwe, J.S.; Stecko, T.D.; Stauffer, J.R. and Carline, R.F. (1996). Combined effects of water temperature and salinity on growth and feed utilization of juvenile Nile tilapia Oreochromis niloticus (Linneaus). Aquacult., 146: 37-46.

Lund, I.; Steenfeldt, S.J. and Hansen, B.W. (2007). Effect of dietary arachidonic acid, eicosapentaenoic acid and docosahexaenoic acid on survival, growth and pigmentation in larvae of common sole (Solea solea L.). Aquaculture, 273: 532-544.

Mackie, A.M.; Adron, J.W. and Grant, P.T. (1980). Chemical nature of the feeding stimulants for the juvenile Dover sole Solea solea (L.). J. Fish Biol., 16: 701708.

Marin-Magan, V.; Anguis, V. and Canavete, J.P. (1995). Uso de alimento inerte en larvas yalevines del lenguado Solea senegalensis. In: V Congreso, Nacional de Acicultura, Orvay, F.C. and Reig, A.C. (eds), Sant Carles de la Rapita, 10-13 May, pp 32-436.

Martinez, I.; Moyano, F.J.; Fernandez-Diaz, C. and Yufera, M. (1999). Digestive enzyme activity during larval development of the Senegal sole (Solea senegalensis). Fish Physiol. Biochem., 21: 317-323.

Mehanna, S.F. (2007). Stock assessment and management of the Egyption sole (Solea aegyptiaca Chabanaud, 1927, Osteichthyes: Soleidae) in the southeastern Mediterranean, Egypt. Turk. J. Zool., 31: 379-388.

Mehanna, S.F. (2014). Reproductive dynamics of the common sole Solea solea (Linnaeus, 1758) from Bardawil lagoon, North Sinai, Egypt. Conference on International Research on Food Security, Natural Resource Management and Rural Development Organized by the Czech University of Life Sciences Prague. Tropentag, September 17-19.

Metailler, R.; Cadena-Roa, M. and Person-Le-Ruyet, J. (1983). Attractive chemical substances for the weaning of Dover sole (Solea vulgaris ): qualitative and quantitative approach. J. World Maric. Soc., 14: 679-684.

Metailler, R.; Menu, B. and Moriniere, P. (1981). Weaning of Dover sole (Solea vulgaris) using artificial diets. J. World Maric. Soc., 12: 111-116. 
Methot, R.D. and Kramer, D. (1979). Growth of Northern Anchovy, Engraulis mordax, larvae in the sea. Fish B-NOAA., 77: 413-423.

Moretti, A.; Fernandez-Criado, M. and Vetillart, R. (2005). Manual on Hatchery Production of Sea bass and Gilthead Sea bream, Volume 2. Fao, Rome, Italy.

Morrison, C.M. and MacDonald, C.A. (1995). Normal and abnormal jaw development of the yolk-sac larva of Atlantic halibut Hippoglossus hippoglossus. Disease of Aquatic Organisms, 22: 173-184.

Moustakas, C.T.; Watanabe, W.O. and Copeland, K.A. (2004). Combined effects of photoperiod and salinity on growth, survival, and osmoregulatory ability of larval southern flounder Paralichthys lethostigma. Aquaculture, 229: 159-179.

NRC (1993). Nutrient requirements of fish. National Research Council National Academy Press, Washington D.C., USA.

Okamura, A.; Yamada, Y.; Horie, N.; Utoh, T.; Mikawa, N. and Tanaka, S. (2007). Effects of water temperature on early development of Japanese eel Anguilla japonica. Fish. Sci., 73: 1241-1248.

Olafsen, J.A. (2001). Interactions between fish larvae and bacteria in marine aquaculture. Aquaculture, 200: 223-247.

Olsen, A.I.; Olsen, Y.; Attramadal, Y.; Christie, K.; Birkbeck, T.H.; Skjermo, J. and Vadstein, O. (2000). Effects of short term feeding of microalgae on the bacterial flora associated with juvenile Artemia franciscana. Aquaculture, 190: 11-25.

O'Neill, B.; De Raedemaecker, F.; McGrath, D. and Brophy, D. (2011). An experimental investigation of salinity effects on growth, development and condition in the European flounder (Platichthys flesus. L.). J. Exp. Mar. Biol. Ecol., 410: 39-44.

Ottesen, O.H. and Bolla, S. (1998). Combined effects of temperature and salinity on development and survival of Atlantic halibut larvae. Aquacul. Int., 6: 103-120.

Palazzi, R.; Richard, J.; Bozzato, G. and Zanella, L. (2006). Larval and juvenile rearing of common sole (Solea solea L.) in the Northern Adriatic (Italy). Aquaculture, 255: 495-506.

Parra, G. and Yufera, M. (1999). Tolerance response to ammonia and nitrite exposure in larvae of two marine fish species (gilthead seabream Sparus aurata L. and Senegal sole Solea senegalensis Kaup). Aquac. Res., 30: 857-863.

Partridge, G.J. and Jenkins, G.I. (2002). The effect of salinity on growth and survival of juvenile black bream (Acanthopagrus butcheri). Aquaculture, 210: 219-230.

Pepin, P. (1991). The effect of temperature and size on development and mortality rates of the pelagic early life history stages of marine fish. Can. J. Fish. Aquat. Sci., 48: 503-518.

Policansky, D. (1982). Influence of age, size, and temperature on metamorphosis in the Starry flounder, Platichthys stellatus. Can. J. Fish Aquat. Sci., 39: 514-517.

Ribeiro, L.; Zambonino-Infante, J.L.; Cahu, C. and Dinis, M.T. (1999). Development of digestive enzymes in larvae of Solea senegalensis, Kaup 1858. Aquaculture, 179: 465-473.

Rosenlund, G.; Stoss, J. and Talbot, C. (1997). Co-feeding marine fish larvae with inert and live diets. Aquaculture, 155: 183-191.

Rueda-Jasso, R.A.; Conceicao, L.E.C.; De Coen, W.; Rees, J.F. and Sorgeloos, P. (2005). Diet and weaning age affect the growth and condition of Dover sole (Solea solea L.). Ciencias Marinas, 31: 477-489.

Saenz de Rodriganez, M.A.; Gander, B.; Alaiz, M. and Moyano, F.J. (2011). Physicochemical characterization and in vitro digestibility of commercial feeds used in weaning of marine fish. Aquac. Nutr., 17: 429-440. 
Salas-Leiton, E.; Anguis, V.; Rodriguez-Rua, A. and Canavate, J.P. (2011). High stocking density and food restriction have minimum impact on size dispersal of cultured Senegalese sole (Solea senegalensis, Kaup 1858) juveniles. Evidence for individual growth being regulated by population structure. Aquacultural Engineering, 45: 43-50.

Salas-Leiton, E.A.; Rodriguez-Rua, A.; Asensio, E.; Infante, C.; Manchado, M.; Fernandez-Diaz, C. and Canavate, J.P. (2012). Effect of salinity on egg hatching, yolk sac absorption and larval rearing of Senegalese sole (Solea senegalensis Kaup 1858). Reviews in Aquaculture, 4: 49-58.

Sampaio, L.A.; Freitas, L.S.; Okamoto, M.H.; Louzada, R.V.; Rodrigues, R.V. and Robaldo, R.B. (2007). Effects of salinity on Brazilian flounder Paralichthys orbignyanus from fertilization to juvenile settlement. Aquaculture, 262: 340346.

Sanchez, P.; Ambrosio, P.P. and Flos, R. (2010). Stocking density and sex influence individual growth of Senegalese sole (Solea senegalensis). Aquaculture, 300: 93-101.

Sims, D.W.; Wearmouth, V.J.; Southall, E.J.; Hill, J.M.; Moore, P.; Rawlinson, K.; Hutchinson, N.; Budd, G.C.; Righton, D.; Metcalfe, J.D.; Nash, J.P. and Morrit, D. (2006). Hunt warm, rest cool: bioenergetic strategy underlying diel vertical migration of a benthic shark. J. Anim. Ecol., 75: 176-190.

SPSS (2008). Statistical Package For Social Science (for Windows). Release 17 Copyright (C), SPSS Inc., Chicago, USA.

Sun, P.L.; Hawkins, W.E.; Overstreet, R.M. and Brown-Peterson, N.J. (2009). Morphological deformities as biomarkers in fish from contaminated rivers in Taiwan. International Journal of Environmental Research and Public Health, 6: 2307-2331.

Swann, L.D. (1997). A fish farmers guide to understanding water quality. IllinoisIndiana Sea Grant Program. AS-503. Purdue University, West Lafayette, Indiana. $8 \mathrm{pp}$.

Vazquez, R.; Gonzalez, S.; Rodriguez, A. and Mourente, G. (1994). Biochemical composition and fatty acid content of fertilized eggs, yolk sac stage larvae and first feeding larvae of the Senegal sole (Solea senegalensis Kaup). Aquaculture, 119: 273-285.

Villalta, M.; Estevez, A.; Bransden, M.P. and Bell, J.G. (2005). The effect of graded concentrations of dietary DHA on growth, survival and tissue fatty acid profile of Senegal sole (Solea senegalensis) larvae during the Artemia feeding period. Aquaculture, 249: 353-365.

Wada, T.; Aritaki, M. and Tanaka, M. (2004). Effects of low salinity on the growth and development of spotted halibut Verasper variegatus in the larva-juvenile transformation period with reference to pituitary prolactin and gill chloride cells responses. J. Exp. Mar. Biol. Ecol., 308: 113-126.

Yamashita, Y.; Tanaka, M. and Millar, J.M. (2001). Ecophysiology of juvenile flatfish in nursery grounds. J. Sea Res., 45: 205-218.

Yufera, M.; Parra, G.; Santiago, R. and Carrascosa, M. (1999). Growth, carbon, nitrogen and caloric content of Solea senegalensis (Pisces: Soleidae) from egg fertilization to metamorphosis. Mar. Biol., 134: 43-49.

Zaki, M.I.; Zaher, M.M.; Kamel, S.A. and Abdel-Kawi, S.S. (1998). Rearing of Solea aegyptiaca larval in lake Quarun, Egypt. Ocean Pulse, edited by Tanacredi and Loret. Plenum Press, New York, pp. 127-136. 
Zarza, C.; Padros, E.; Estevez, A.; Crespo, S. and Furones, M.D. (2003). New fish species for aquaculture, old pathological problems: the case of Solea sp. Proc. $11^{\text {th }}$ European Assoc. Fish Pathologist. St Jubens, Malta.

\section{ARABIC SUMMARY}

تأثير بعض نظم الرعاية على نمو وتطور يرقات أسماك موسى المصرية

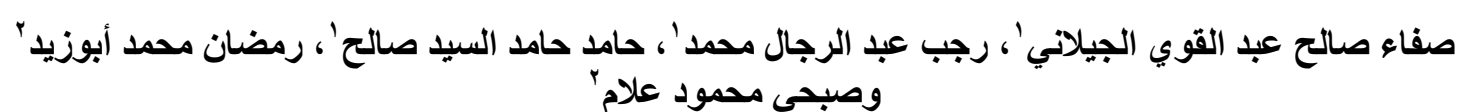

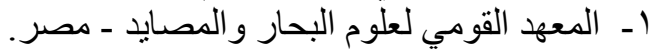

r ـ قسم الانتاج الحيو اني، كلية الزر البحارة، جامعة الفيوم، مصر.

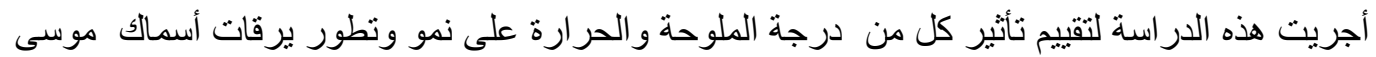

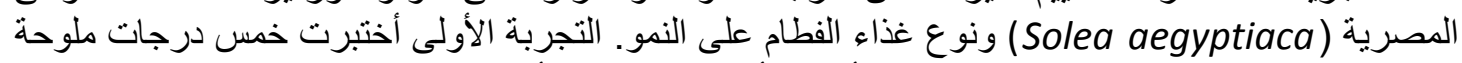

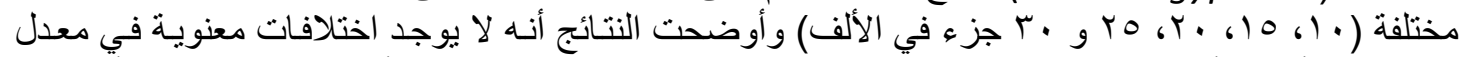

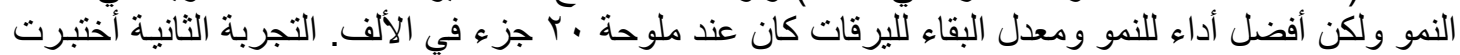

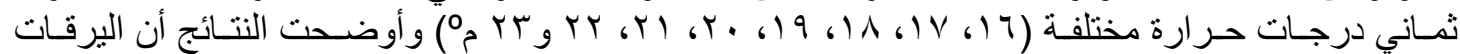

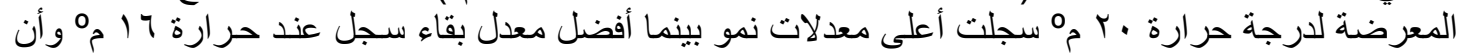

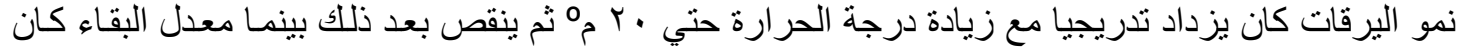

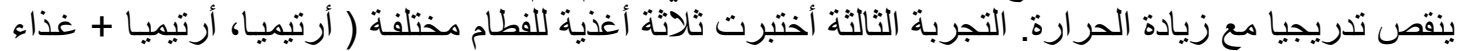
صناعي و غذاء صناعي) و أوضحت النتائج أن أعلى معدلات نمو سجلت عند التغذية على الأرتيميا فقط.
} 